\title{
FAKTOR RISIKO KEJADIAN STUNTING PADA ANAK USIA 2-3 TAHUN (Studi di Kecamatan Semarang Timur)
}

\author{
Kukuh Eka Kusuma, Nuryanto*) \\ Program Studi Ilmu Gizi Fakultas Kedokteran Universitas Diponegoro \\ Jl.Dr.Sutomo No.18, Semarang, Telp (024) 8453708, Email : gizifk@ undip.ac.id
}

\begin{abstract}
Background: Stunting is a chronic condition that shows a delayed growth because of chronic malnutrition, showed by z-score height for age <-2SD. Stunting prevalence in children under five in Indonesia was high especially at age 2-3. There was many risk factor of stunting such as birth length, food intake, infection and disease, genetic and family socio-economic status. Stunting at children aged 2 or older is harder to overcome compared to younger age. Study concerning this problem is needed.

Methods : an observational study with case control design on children aged 2-3 years at East Semarang sub district. Sample was selected by consecutive sampling with 36 subject for each group. Subject and respondent identity, child birth length, parents educational degree, parents occupation, family income and family member was collected using questionnaire. Children height and parents height was measured using microtoise. Bivariate analyzed with chi-square for determining odds ratio and multivariate with multiple logistic regression.

Results : Multivariate analysis showed risk factor for children aged 2-3 years was low family economic status $(P=$ 0,032; OR = 4,13). Child birth length, parents height and parents educational degree was non significant risk factors.

Conclusion : Low family economic status is significant risk factor of stunting among children aged 2-3 years. Children with low family economic status is 4,13 higher at risk of becoming stunting.
\end{abstract}

Keywords : Stunting; children; risk factors

\begin{abstract}
ABSTRAK
Latar Belakang: Stunting merupakan kondisi kronis yang menggambarkan terhambatnya pertumbuhan karena malnutrisi jangka panjang, ditunjukkan dengan nilai z-score TB/U kurang dari -2SD. Prevalensi stunting pada balita di Indonesia masih tinggi terutama pada usia 2-3 tahun. Faktor risko stunting antara lain panjang badan lahir, asupan, penyakit dan infeksi, genetik, dan status sosial ekonomi keluarga. Stunting terutama pada anak usia diatas 2 tahun sulit diatasi, sehingga penelitian mengenai faktor risiko stunting pada anak usia diatas 2 tahun diperlukan.

Metode: Penelitian observasional dengan desain case-control pada balita usia 2-3 tahun di wilayah kecamatan Semarang Timur. Pengambilan sampel dilakukan dengan consecutive sampling, 36 subjek pada tiap kelompok. Stunting dikategorikan berdasarkan nilai z-score tinggi badan menurut umur (TB/U). Data identitas subjek dan responden, panjang badan lahir, pendidikan orang tua, pekerjaan orang tua, pendapatan keluarga dan jumlah anggota keluarga diperoleh melalui wawancara dengan kuesioner. Data tinggi badan anak dan tinggi badan orang tua diukur menggunakan microtoise. Analisis bivariat menggunakan Chi-Square dengan melihat Odds Ratio (OR) dan multivariat dengan regresi logistik ganda.

Hasil: Hasil analisis multivariat menunjukkan bahwa faktor risiko stunting pada balita usia 2-3 tahun adalah status ekonomi keluarga yang rendah $(P=0,032 ; O R=4,13)$, sedangkan panjang badan lahir, tinggi badan orangtua, dan pendidikan orang tua bukan merupakan faktor risiko stunting.

Kesimpulan: Status ekonomi keluarga yang rendah merupakan faktor risiko yang bermakna terhadap kejadian stunting pada balita usia 2-3 tahun. Anak dengan status ekonomi keluarga yang rendah lebih berisiko 4,13 kali mengalami stunting.
\end{abstract}

Kata Kunci : Stunting; Balita; Faktor Risiko

\section{PENDAHULUAN}

Stunting merupakan kondisi kronis yang menggambarkan terhambatnya pertumbuhan karena malnutrisi jangka panjang. Stunting menurut WHO Child Growth Standart didasarkan pada indeks panjang badan dibanding umur $(\mathrm{PB} / \mathrm{U})$ atau tinggi badan dibanding umur (TB/U) dengan batas (z-score) kurang dari -2 SD. ${ }^{1}$
Stunting pada balita perlu menjadi perhatian khusus karena dapat menghambat perkembangan fisik dan mental anak. Stunting berkaitan dengan peningkatan risiko kesakitan dan kematian serta terhambatnya pertumbuhan kemampuan motorik dan mental. ${ }^{2}$ Balita yang mengalami stunting memiliki risiko terjadinya penurunan kemampuan intelektual, produktivitas, 
dan peningkatan risiko penyakit degeneratif di masa mendatang. ${ }^{3}$ Hal ini dikarenakan anak stunting juga cenderung lebih rentan terhadap penyakit infeksi, sehingga berisiko mengalami penurunan kualitas belajar di sekolah dan berisiko lebih sering absen. ${ }^{4}$ Stunting juga meningkatkan risiko obesitas, karena orang dengan tubuh pendek berat badan idealnya juga rendah. Kenaikan berat badan beberapa kilogram saja bisa menjadikan Indeks Massa Tubuh (IMT) orang tersebut naik melebihi batas normal. Keadaan overweight dan obesitas yang terus berlangsung lama akan meningkatan risiko kejadian penyakit degeneratif. ${ }^{3}$

Banyak faktor yang mempengaruhi stunting, diantaranya adalah panjang badan lahir, status ekonomi keluarga, tingkat pendidikan dan tinggi badan orang tua. Panjang badan lahir pendek merupakan salah satu faktor risiko stunting pada balita. Panjang badan lahir pendek bisa disebabkan oleh faktor genetik yaitu tinggi badan orang tua yang pendek, maupun karena kurangnya pemenuhan zat gizi pada masa kehamilan. Panjang badan lahir pendek pada anak menunjukkan kurangnya zat gizi yang diasup Ibu selama masa kehamilan, sehingga pertumbuhan janin tidak optimal yang mengakibatkan bayi yang lahir memiliki panjang badan lahir pendek. ${ }^{3,6}$ Panjang badan lahir berkaitan erat dengan tinggi badan orang tua. ${ }^{7}$ Ibu dengan tinggi badan pendek lebih berpeluang utntuk melahirkan anak yang pendek pula. Penelitian di Mesir menunjukkan bahwa anak yang lahir dari Ibu dengan tinggi badan kurang dari $150 \mathrm{~cm}$ lebih berisiko untuk tumbuh stunting. ${ }^{7}$ Penelitian di Semarang menunjukkan bahwa tinggi badan Ibu dan ayah yang pendek merupakan faktor risiko stunting pada anak usia $12-36$ bulan. ${ }^{8,9}$

Selain panjang badan lahir dan tinggi badan orang tua, status ekonomi keluarga dan pendidikan orang tua juga merupakan faktor risiko kejadian stunting pada balita. Status ekonomi keluarga dipengaruhi oleh beberapa faktor, antara lain pekerjaan orang tua, tingkat pendidikan orang tua dan jumlah anggota keluarga. ${ }^{10}$ Status ekonomi keluarga akan mempengaruhi kemampuan pemenuhan gizi keluarga maupun kemampuan mendapatkan layanan kesehatan. Anak pada keluarga dengan tingkat ekonomi rendah lebih berisiko mengalami stunting karena kemampuan pemenuhan gizi yang rendah, meningkatkan risiko terjadinya malnutrisi. ${ }^{10}$ Tingkat pendidikan orang tua yang rendah juga disinyalir meningkatkan risiko malnutrisi pada anak. Tingkat pendidikan orang tua akan berpengaruh terhadap pengetahuan orang tua terkait gizi dan pola pengasuhan anak, dimana pola asuh yang tidak tepat akan meningkatkan risiko kejadian stunting. ${ }^{11}$

Stunting pada masa balita perlu mendapat perhatian khusus termasuk pada anak usia 2-3 tahun. Proses pertumbuhan pada usia 2-3 tahun cenderung mengalami perlambatan sehingga peluang untuk terjadinya kejar tumbuh lebih rendah dibanding usia 0-2 tahun. Usia 2-3 tahun merupakan usia anak mengalami perkembangan yang pesat dalam kemampuan kognitif dan motorik. Diperlukan kondisi fisik yang maksimal untuk mendukung perkembangan ini, dimana pada anak yang stunting perkembangan kemampuan motorik maupun kognitif dapat terganggu. ${ }^{5,7}$ Anak pada usia ini juga membutuhkan perhatian lebih dalam hal asupan karena kebutuhan energi yang lebih tinggi dan kebutuhan makanan yang lebih bervariasi dibanding usia 0-2 tahun. ${ }^{5}$

Prevalensi stunting di Indonesia masih tinggi. Berdasarkan Riset Kesehatan Dasar (Riskesdas) tahun 2010, prevalensi stunting di Indonesia tahun 2010 sebesar 35,6\%, sebagian besar terjadi pada anak usia 2-3 tahun yaitu $41,4 \%$ dari total populasi anak stunting di Indonesia. ${ }^{13}$ Prevalensi stunting di Jawa Tengah tergolong tinggi yaitu sebesar 33,6\% dengan perincian $17 \%$ anak pendek dan $16,9 \%$ anak sangat pendek. ${ }^{13}$ Salah satu wilayah di Jawa Tengah dengan prevalensi stunting tinggi adalah Kota Semarang. Menurut profil kesehatan kota Semarang tahun 2011 prevalensi balita stunting adalah 20,66\%, dan Kecamatan Semarang Timur merupakan kecamatan dengan prevalensi stunting tertinggi, yaitu 40,16\%. ${ }^{9}$ Tujuan dari penelitian ini adalah menganalisis faktor risiko panjang badan lahir, status ekonomi keluarga, tingkat pendidikan dan tinggi badan orang tua terhadap kejadian stunting pada anak usia 2-3 tahun.

\section{METODE}

Penelitian ini dilaksanakan pada bulan Juli 2013 di kecamatan Semarang Timur, yaitu di wilayah kerja Puskesmas Bugangan meliputi wilayah kelurahan Bugangan, Mlatiharjo, dan Kebonagung. Jenis penelitian observasional dengan rancangan case-control. Populasi target dalam penelitian ini adalah semua anak usia 2-3 tahun di wilayah Kota Semarang, sedangkan populasi terjangkau adalah semua anak usia 2-3 tahun di wilayah kerja Puskesmas Bugangan. Subyek dalam penelitian ini adalah semua kasus dan kontrol yang dipilih dengan perbandingan kasus dan kontrol 1:1. Kasus adalah balita usia 2-3 
tahun dengan indeks $z$-score $\mathrm{TB} / \mathrm{U} \leq-2 \mathrm{SD}$, sedangkan kontrol adalah balita usia 2-3 tahun dengan indeks $z$-score TB/U -2SD s/d +2SD. Responden dalam penelitian ini adalah Ibu balita yang terpilih menjadi subyek penelitian. Kriteria inklusi dalam penelitian ini adalah balita berusia 23 tahun yang tinggal dan menetap di Semarang Timur, tidak sakit maupun cacat dan tinggal bersama kedua orang tua, serta memiliki Kartu Menuju Sehat (KMS). Jumlah subyek pada masing-masing kelompok sebanyak 36 subyek yang dihitung menggunakan rumus untuk besar sampel kasus kontrol dan ditambah $10 \%$ untuk mengantisipasi drop out.

Variabel terikat dalam penelitian ini adalah stunting, sedangkan variabel bebas adalah panjang badan lahir, status ekonomi keluarga, tingkat pendidikan dan tinggi badan orang tua. Data yang dikumpulkan antara lain identitas subyek, tinggi badan balita saat ini, panjang badan lahir balita, tinggi badan ayah dan Ibu balita, pendidikan ayah dan Ibu balita, pekerjaan ayah dan Ibu balita, pendapatan total keluarga, dan jumlah anggota keluarga.

Panjang badan lahir adalah panjang badan ketika bayi baru lahir yang didapat dari data di KMS, kemudian data yang didapat dikonversi kedalam bentuk nilai indeks $z$-score $\mathrm{TB} / \mathrm{U}$ dimana bila hasilnya $\leq-2$ SD maka dikategorikan panjang badan lahir pendek, dan bila hasilnya >-2SD dikategorikan panjang badan lahir tidak pendek. ${ }^{14}$ Tinggi badan orang tua adalah hasil ukur antropometri dilihat dari tinggi badan ibu dan ayah subjek yang diukur dengan alat microtoise dengan ketelitian $0,1 \mathrm{~cm}$, kemudian data dikategorikan sesuai penelitian sebelumnya. Ibu dikategorikan pendek jika tinggi badan $\leq 150 \mathrm{~cm}$ dan tidak pendek jika $>150 \mathrm{~cm}$, sedangkan ayah dikategorikan pendek jika tinggi badan $\leq 162 \mathrm{~cm}$ dan tidak pendek jika $>162 \mathrm{~cm}$. $^{7,1}$

Status ekonomi keluarga dinyatakan berdasarkan kategori pendapatan perkapita.
Pendapatan perkapita yaitu besar pendapatan total yang diperoleh keluarga dalam satu bulan terakhir kemudian dibagi jumlah anggota keluarga. Data pendapatan perkapita kemudian dikategorikan menurut batas garis kemiskinan dari BPS Kota Semarang. Pendapatan perkapita dinyatakan rendah jika $\leq \mathrm{Rp} 246.195$ dan status ekonomi keluarga dinyatakan rendah, dan pendapatan perkapita dinyatakan tinggi jika > Rp 246.195 dan status ekonomi keluarga dinyatakan tinggi. ${ }^{16}$ Pendidikan orang tua adalah jenjang pendidikan formal terakhir yang ditamatkan orang tua berdasarkan kepemilikan ijazah. Tingkat pendidikan kemudian akan dibagi menjadi tingkat pendidikan ayah dan ibu. Tingkat pendidikan dikategorikan rendah jika orang tua maksimal tamat Sekolah Menengah Pertama (SMP) / sederajat, dan dikategorikan tinggi jika minimal tamat Sekolah Menengah Atas (SMA) / sederajat.

Uji statistik untuk melihat besar risiko panjang badan lahir, status ekonomi keluarga, tingkat pendidikan dan tinggi badan orang tua terhadap kejadian stunting menggunakan uji Chi Square yaitu dengan melihat Odds Ratio (OR) dan uji regresi logistik ganda untuk melihat faktor yang paling berpengaruh terhadap kejadian stunting.

\section{HASIL PENELITIAN \\ Karakterististik Subyek dan responden}

Jumlah subyek pada awal penelitian sebanyak 72 balita usia 24-36 bulan yang terdiri dari 36 kasus dan 36 kontrol. Saat pengambilan data, 2 subyek drop out karena satu anak pada kelompok kasus orangtuanya tinggal di luar kota sehingga tidak bisa dilakukan pengukuran terhadap tinggi badan orang tua, sedangkan satu anak pada kelompok kontrol orang tuanya (ibu) meninggal dunia, sehingga jumlah subyek valid sebanyak 70 anak, 35 anak masing-masing kelompok. Adapun karakteristik subyek sebagai berikut.

Tabel 1. Distribusi frekuensi jenis kelamin subyek, pekerjaan orang tua dan tingkat pendidikan orang tua

\begin{tabular}{lllccc}
\hline & & \multicolumn{2}{c}{ Kasus } & \multicolumn{2}{c}{ Kontrol } \\
\cline { 3 - 6 } & & $\mathrm{n}$ & $\%$ & $\mathrm{n}$ & $\%$ \\
\hline 1 & Jenis Kelamin & & & & \\
& $-\quad$ Laki-laki & 22 & 62,9 & 22 & 62,9 \\
& $-\quad$ Perempuan & 13 & 37,1 & 13 & 37,1 \\
\hline 2 & Pekerjaan Ibu & & & & \\
& $-\quad$ Tidak Bekerja & 18 & 51,4 & 19 & 54,3 \\
& $-\quad$ Bekerja & 17 & 48,6 & 16 & 45,8 \\
\hline
\end{tabular}




\begin{tabular}{|c|c|c|c|c|c|}
\hline 3 & $\begin{array}{l}\text { Pekerjaan Ayah } \\
-\quad \text { Tidak Bekerja } \\
-\quad \text { Bekerja }\end{array}$ & $\begin{array}{l}0 \\
35\end{array}$ & $\begin{array}{l}0,0 \\
100,0\end{array}$ & $\begin{array}{l}0 \\
35\end{array}$ & $\begin{array}{l}0,0 \\
100,0\end{array}$ \\
\hline \multirow[t]{5}{*}{4} & Pendidikan Ayah & & & & \\
\hline & - $\quad$ Tamat SD & 4 & 11,4 & 5 & 14,3 \\
\hline & - $\quad$ Tamat SMP & 10 & 28,6 & 5 & 14,3 \\
\hline & - Tamat SMA & 16 & 45,7 & 17 & 48,6 \\
\hline & - $\quad$ Tamat Perguruan Tinggi & 5 & 14,3 & 8 & 22,9 \\
\hline \multirow[t]{5}{*}{5} & Pendidikan Ibu & & & & \\
\hline & - $\quad$ Tamat SD & 3 & 8,6 & 3 & 8,6 \\
\hline & - $\quad$ Tamat SMP & 9 & 25,7 & 5 & 14,3 \\
\hline & - Tamat SMA & 21 & 60 & 17 & 48,6 \\
\hline & - $\quad$ Tamat Perguruan Tinggi & 2 & 5,7 & 10 & 28,6 \\
\hline
\end{tabular}

Sebagian besar subyek penelitian ini berjenis kelamin laki-laki, yaitu sebanyak 44 anak, sementara perempuan hanya 26 anak. Hasil uji beda menunjukkan tidak ada perbedaan berdasarkan kelompok kasus kontrol antara anak laki-laki dengan anak perempuan. Median nilai zscore tinggi badan dibanding umur adalah -1.82 SD dengan nilai minimal -5.37 SD dan nilai maksimal 1.16 SD. Karakteristik responden (dalam hal ini Ibu subyek) sebanyak 37 orang $(52,9 \%)$ adalah tidak bekerja (Ibu rumah tangga). Jumlah ibu berpendidikan rendah pada kelompok kasus sebanyak 34,2\%, sedangkan pada kelompok kontrol hanya $22,8 \%$. Sebanyak $40 \%$ ayah pada kelompok kasus berpendidikan rendah, sedangkan pada kelompok kontrol hanya $28,6 \%$.

Analisa univariat dilakukan untuk melihat median dan nilai minimal-maksimal. Tabel 2 berikut menunjukkan hasil analisa univariat panjang badan lahir, tinggi badan ayah, tinggi badan ibu, dan pendapata perkapita.

Tabel 2. Tabel deskriptif panjang badan lahir, tinggi badan ayah, tinggi badan ibu, dan pendapatan perkapita

\begin{tabular}{rrrr}
\hline & Variabel & Kasus & Kontrol \\
\hline 1 & Panjang badan lahir & & \\
& $-\quad$ median & $49,0 \mathrm{~cm}$ & $50,0 \mathrm{~cm}$ \\
& - minimum & $40,0 \mathrm{~cm}$ & $43,0 \mathrm{~cm}$ \\
& - maksimum & $52,0 \mathrm{~cm}$ & $56,0 \mathrm{~cm}$ \\
& & & \\
\hline 2 & Tinggi badan ayah & $165,0 \mathrm{~cm}$ \\
& - median & $163,70 \mathrm{~cm}$ & $152,0 \mathrm{~cm}$ \\
& - minimum & $150,0 \mathrm{~cm}$ & $185,0 \mathrm{~cm}$
\end{tabular}

$3 \quad$ Tinggi badan ibu

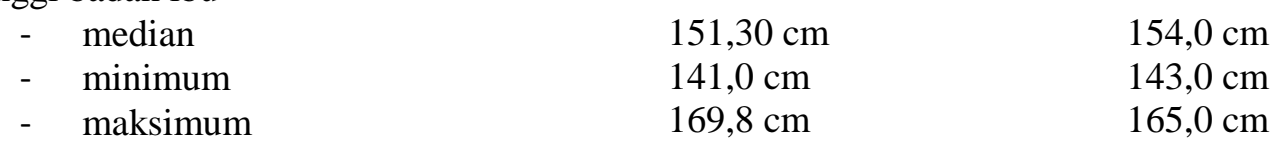

$4 \quad$ Pendapatan per-kapita

$\begin{array}{llll}- & \text { median } & \mathrm{Rp} 333.334,0 & \mathrm{Rp} 600.000 \\ - & \text { minimum } & \mathrm{Rp} 150.000 & \mathrm{Rp} 180.000 \\ - & \text { maksimum } & \mathrm{Rp} 1.333 .334 & \mathrm{Rp} 1.666 .667\end{array}$




\section{Faktor Risiko Stunting}

Analisa bivariat dan multivariat dilakukan untuk mengetahui nilai odd ratio dan menentukan faktor mana yang merupakan faktor risiko stunting. Tabel 3 menunjukkan hasil analisa bivariat sedangkan tabel 4 menunjukkan hasil analisa multivariat.

Tabel 3.Besar risiko panjang badan lahir, tinggi badan orangtua, pendidikan orangtua dan status ekonomi keluarga terhadap kejadian stunting

${ }^{\mathrm{a}}$ Uji Chi Square, ${ }^{\mathrm{b}} \mathrm{P}<0,05$

\begin{tabular}{|c|c|c|c|c|c|c|c|}
\hline & \multirow{2}{*}{ Variabel } & \multicolumn{2}{|c|}{ Kasus } & \multicolumn{2}{|c|}{ Kontrol } & \multirow[b]{2}{*}{$p$} & \multirow{2}{*}{$\begin{array}{c}\text { OR } \\
(95 \% \mathrm{Cl})\end{array}$} \\
\hline & & $\mathrm{n}$ & $\%$ & $\mathrm{n}$ & $\%$ & & \\
\hline \multirow[t]{3}{*}{1} & Kategori panjang badan lahir & & & & & \multirow{3}{*}{$0,172^{\mathrm{a}}$} & \\
\hline & - Stunting & 7 & 20 & 3 & 8,6 & & 2.667 \\
\hline & - $\quad$ Tidak Stunting & 28 & 80 & 32 & 91,4 & & $(0.629-11.306)$ \\
\hline \multirow[t]{3}{*}{2} & Tinggi Badan Ayah & & & & & \multirow{3}{*}{$0,138^{\mathrm{a}}$} & \\
\hline & - $\quad$ Pendek $(\leq 162 \mathrm{~cm})$ & 16 & 45,7 & 10 & 28,6 & & 2.105 \\
\hline & - $\quad$ Tidak Pendek $(>162 \mathrm{~cm})$ & 19 & 54,3 & 25 & 71,4 & & $(0,782-5,666)$ \\
\hline \multirow[t]{3}{*}{3} & Tinggi Badan Ibu & & & & & \multirow{3}{*}{$0,048^{\mathrm{a}, \mathrm{b}}$} & \\
\hline & - $\quad$ Pendek $(\leq 150 \mathrm{~cm})$ & 17 & 48,6 & 9 & 25,7 & & 2,728 \\
\hline & - $\quad$ Tidak Pendek $(>150 \mathrm{~cm})$ & 18 & 51,4 & 26 & 74,3 & & $(0,997-7,468)$ \\
\hline \multicolumn{8}{|c|}{4 Pendidikan Ayah } \\
\hline & - $\quad$ Rendah $(\leq \mathrm{SMP})$ & 14 & 20,0 & 10 & 14,3 & \multirow[t]{2}{*}{$0,314^{\mathrm{a}}$} & 1,667 \\
\hline & - $\quad$ Tinggi ( $\geq$ SMA) & 21 & 30,0 & 25 & 35,7 & & $(0,615-4,519)$ \\
\hline \multicolumn{8}{|c|}{5 Pendidikan Ibu } \\
\hline & - $\quad$ Rendah $(\leq \mathrm{SMP})$ & 12 & 17,1 & 8 & 11,4 & \multirow{2}{*}{$0,290^{\mathrm{a}}$} & 1,761 \\
\hline & - $\quad$ Tinggi ( $\geq$ SMA) & 23 & 32,9 & 27 & 38,6 & & $(0,614-5,049)$ \\
\hline \multicolumn{8}{|c|}{$\begin{array}{ll}6 & \text { Kategori Status Ekonomi Keluarga }\end{array}$} \\
\hline & - Rendah & 13 & 37,1 & 4 & 11,4 & \multirow{2}{*}{$0,012^{\mathrm{a}, \mathrm{b}}$} & 4,580 \\
\hline & - $\quad$ Tinggi & 22 & 62,9 & 31 & 88,6 & & $(1,316-15,932)$ \\
\hline
\end{tabular}

Variabel yang diikutsertakan dalam analisa

keluarga. Pendidikan ayah dan pendidikan ibu multivariat adalah panjang badan lahir, tinggi tidak diikutsertakan dalam analisa karena tidak badan ibu, tinggi badan ayah dan status ekonomi memenuhi syarat untuk analisa multivariat.

Tabel 4. Hasil analisa regresi logistik ganda faktor yang paling berpengaruh terhadap kejadian stunting

\begin{tabular}{|c|c|c|c|c|}
\hline Variabel & Koefisien & $p$ & OR & $95 \%[\mathrm{CI}]$ \\
\hline $\begin{array}{lll}\begin{array}{l}\text { Kategori } \\
\text { keluarga }\end{array} & \text { status } & \text { ekonomi } \\
\end{array}$ & 1,420 & 0,032 & 4,137 & $1,127-15,181$ \\
\hline Kategori tinggi badan ibu & 1,000 & 0,069 & 2,718 & $0,924-7,997$ \\
\hline Kategori tinggi badan ayah & 0,668 & 0,228 & 1,951 & $0,658-5,784$ \\
\hline Panjang badan lahir & 0,919 & 0,242 & 2,507 & $0,537-11,689$ \\
\hline Konstanta & $-1,061$ & 0,130 & 0,346 & \\
\hline
\end{tabular}

Hasil analisa bivariat maupun multivariat menunjukkan bahwa status ekonomi yang rendah merupakan faktor risiko kejadian stunting. Anak dengan status ekonomi keluarga rendah 4,13 kali lebih berisiko untuk tumbuh stunting dibanding anak dengan status ekonomi keluarga tinggi. Panjang badan lahir, tinggi badan ayah, tinggi badan ibu, pendidikan ayah dan pendidikan ibu tidak terbukti menjadi faktor risiko stunting. Sebanyak $37,1 \%$ subyek pada kelompok kasus termasuk kategori status ekonomi rendah, sedangkan pada kelompok kontrol hanya 11,4\% subyek yang termasuk kategori status ekonomi rendah. Hasil penelitian ini menunjukkan bahwa subjek pada kelompok kasus memiliki pendapatan per kapita yang berkisar antara Rp 150.000 - Rp 1.333.330, dengan median Rp 333.334.

\section{PEMBAHASAN}

Hasil penelitian ini menunjukkan bahwa panjang badan lahir bukan merupakan faktor risiko stunting. Hasil ini tidak sesuai dengan penelitian di 
Pati yang menunjukkan hasil bahwa panjang badan lahir merupakan faktor risiko kejadian stunting pada anak usia 12-36 bulan, dan penelitian di Indramayu yang menunjukkan hasil bahwa anak yang lahir dengan panjang badan dibawah persentil -10 lebih berisiko tumbuh stunting. ${ }^{3,17}$ Panjang badan lahir tidak menjadi faktor risiko stunting dikarenakan faktor risiko yang mempengaruhi stunting banyak sekali dan dalam penelitian ini tidak dilihat seperti riwayat kehamilan, asupan makan anak maupun pola asuh. Bayi dengan panjang badan lahir pendek berpeluang lebih tinggi untuk tumbuh pendek dibanding anak panjang badan lahir normal. ${ }^{17}$ Anak dengan panjang badan lahir pendek menunjukkan kurangnya gizi yang diasup Ibu selama masa kehamilan, sehingga pertumbuhan janin tidak optimal yang mengakibatkan bayi yang lahir memiliki panjang badan lahir yang rendah. ${ }^{17}$ Faktor asupan dan penyakit memegang peranan yang menentukan apakah anak yang lahir dengan panjang badan lahir rendah akan tetap stunting selama masa hidupnya atau berhasil mencapai catch-up grow yang maksimal. ${ }^{3,6,18}$ Anak yang lahir dengan panjang badan lahir pendek memang lebih berisiko untuk tumbuh stunting dibanding anak yang lahir dengan panjang badan normal, tetapi selama anak tersebut mendapatkan asupan yang memadai dan terjaga kesehatannya, maka kondisi panjang badan lahir yang pendek dapat dikejar dengan pertumbuhan seiring bertambahnya usia anak. ${ }^{18}$ Hal ini terlihat dari hasil penelitian di Tangerang yang menemukan bahwa panjang badan lahir merupakan faktor risiko stunting yang masih dapat diatasi. Anak dengan panjang badan lahir pendek akan tetap stunting sampai usia 6-12 bulan, namun dapat mencapai tinggi badan normal pada usia 3-4 tahun. $^{19}$

Hasil penelitian ini menunjukkan bahwa tinggi badan Ibu maupun ayah bukan merupakan faktor risiko stunting. Hasil ini tidak sesuai dengan penelitian di Semarang tahun 2011 yang menunjukkan bahwa tinggi badan Ibu yang rendah merupakan faktor risiko stunting pada anak usia 24-36 bulan. ${ }^{8,9}$ Penelitian di Bangladesh juga menunjukkan bahwa banyak ditemukan anak stunting pada keluarga yang memiliki Ibu dengan tinggi badan $<148 \mathrm{~cm} .{ }^{20}$ Tinggi badan orang tua tidak menjadi faktor risiko stunting disebabkan karena pada penelitian ini tidak diteliti faktorfaktor yang mempengaruhi tinggi badan orang tua, sehingga tidak bisa dibedakan apakah tinggi badan orang tua saat ini merupakan pengaruh genetik atau karena pengaruh patologis maupun malnutrisi.
Tinggi badan merupakan salah satu bentuk dari ekspresi genetik, dan merupakan faktor yang diturunkan kepada anak serta berkaitan dengan kejadian stunting. Anak dengan orang tua yang pendek, baik salah satu maupun keduanya, lebih berisiko untuk tumbuh pendek dibanding anak dengan orang tua yang tinggi badannya normal. ${ }^{21}$ Orang tua yang pendek karena gen dalam kromosom yang membawa sifat pendek kemungkinan besar akan menurunkan sifat pendek tersebut kepada anaknya. Tetapi bila sifat pendek orang tua disebabkan karena masalah nutrisi maupun patologis, maka sifat pendek tersebut tidak akan diturunkan kepada anaknya. ${ }^{22}$ Penelitian ini menemukan jumlah ayah pendek pada kelompok kasus 16 orang $(45,7 \%)$, sedangkan Ibu pendek pada kelompok kasus 17 orang (48,6\%). Meskipun tidak terbukti sebagai faktor risiko, ibu dan ayah yang pendek lebih banyak ditemukan pada kelompok kasus dibanding kelompok kontrol. Hal ini menunjukkan adanya kecenderungan bahwa anak yang pendek memiliki orangtua yang pendek pula.

Penelitian ini menunjukkan bahwa pendidikan ayah dan ibu bukan merupakan faktor risiko stunting. Hal ini tidak sesuai dengan penelitian di Libya tahun 2008 dan di Semarang tahun 2012 yang menyatakan bahwa pedidikan ayah yang rendah merupakan faktor risiko stunting pada anak balita ${ }^{8,21}$ Penelitian di Bangladesh juga menemukan bahwa nilai z-skor tinggi badan menurut umur lebih baik pada anak dengan ibu yang berpendidikan tinggi dibanding pada anak dengan ibu berpendidikan rendah. ${ }^{20}$ Pendidikan orang tua tidak menjadi faktor risiko stunting disebabkan karena faktor risiko terjadinya stunting banyak, dimana dalam penelitian ini tidak semua faktor dilihat seperti pola asuh dan asupan. Pendidikan orang tua mempunyai pengaruh langsung terhadap pola pengasuhan anak yang kemudian akan mempengaruhi asupan makan anak. Penelitian di Bogor tahun 2005 meyebutkan bahwa pendidikan orang tua berpengaruh langsung terhadap pola pengasuhan anak, dimana pola pengasuhan yang kurang baik akan menyebabkan asupan yang diperoleh anak menjadi kurang baik sehingga mengakibatkan anak tumbuh stunting. ${ }^{23}$ Penelitian di Tangerang Banten tahun 2011 menemukan bahwa pendidikan ayah berhubungan erat dengan perubahan tinggi badan anak stunting pada usia 6-12 bulan menjadi tidak stunting pada usia 3-4 tahun. ${ }^{19}$ Orang tua dengan pendidikan yang lebih baik cenderung memiliki pengetahuan dan kemampuan mengimplementasikan 
pengetahuan yang lebih baik dibanding orang tua dengan pendidikan rendah. ${ }^{8,24}$. Penerapan pengetahuan gizi dan pola asuh anak yang tepat akan mencegah terjadinya malnutrisi, misalnya dalam pemberian makanan pendamping yang tepat usia. $^{25,26}$

Hasil analisis bivariat dan multivariat menunjukkan bahwa status ekonomi keluarga yang rendah merupakan faktor risiko kejadian stunting pada balita usia 2-3 tahun. Hasil ini sesuai dengan hasil penelitian di Bangladesh tahun 2011, dan juga di Brazil tahun 2008 yang menyatakan bahwa status sosial ekonomi yang rendah merupakan faktor risiko kejadian stunting pada anak balita. ${ }^{19,27}$ Penelitian pada anak usia 2-3 tahun di Semarang tahun 2012 menyatakan bahwa status ekonomi yang rendah berhubungan dengan keterbatasan keluarga dalam memenuhi kebutuhan akan zat gizi baik makro maupun mikro. ${ }^{8}$ Status ekonomi keluarga yang rendah akan mempengaruhi kualitas maupun kuantitas bahan makanan yang dikonsumsi oleh keluarga. Makanan yang didapat biasanya akan kurang bervariasi dan sedikit jumlahnya terutama pada bahan pangan yang berfungsi untuk pertumbuhan anak seperti sumber protein, vitamin dan mineral, sehingga meningkatkan risiko kurang gizi. Keterbatasan ini akan meningkatkan risiko terjadinya stunting pada anak balita. ${ }^{8,23}$

\section{SIMPULAN}

Status ekonomi keluarga yang rendah merupakan faktor risiko stunting pada anak usia 23 tahun. Anak pada keluarga dengan status ekonomi rendah memiliki risiko stunting 4,13 kali lebih besar dibanding anak dengan status ekonomi keluarga tinggi. Panjang badan lahir, tinggi badan ayah, tinggi badan Ibu, pendidikan terakhir ibu dan pendidikan terakhir ayah bukan merupakan faktor risiko stunting.

\section{SARAN}

Perlu dilakukan penelitian lebih lanjut mengenai faktor risiko kejadian stunting pada anak usia 2-3 tahun dengan variabel belum tercakup dalam penelitian ini. Penelitian mengenai penyebab stunting pada anak dengan keluarga berstatus ekonomi rendah juga perlu dilakukan agar kejadian stunting pada keluarga berstatus ekonomi rendah dapat dicegah. Perencanaan program penanggulangan stunting perlu memperhatikan faktor status ekonomi keluarga.

\section{DAFTAR PUSTAKA}

1. Nutrition landscape information system (NLIS) country prfile indicators: intrepretation guide. Geneva: World Health Organization; 2010.

2. Purwandini K, Kartasurya M I.Pengaruh Pemberian Mikronutrient Sprinkle Terhadap Perkembangan Motorik Anak Stunting Usia 12-36 Bulan. Journal of Nutrition College 2013; Volume 2 Nomor 1 Halaman 147-163.

3. Anugraheni, H. S. Faktor Risiko Kejadian Stunting pada Anak Usia 12-36 Bulan di Kecamatan Pati, Kabupaten Pati. Program Studi Ilmu Gizi Fakultas Kedokteran Universitas Diponegoro. Semarang; 2012.

4. Yunitasari L. Perbedaan Intellegence Quotient (IQ) Antara Anak Stunting dan Tidak Stunting Umur 712 tahun di Sekolah Dasar (Studi pada Siswa SD Negeri Buara 04 Kecamatan Ketanggungan Kabupaten Brebes). Jurnal Kesehatan Masyarakat 2012; Volume 1 Nomor 2 Halaman 586-595.

5. Yupi Supartini. Buku ajar konsep dasar keperawatan anak. Jakarta: EGC;2004.

6. Rahayu L.S, Sofyaningsih M. Pengaruh BBLR (Berat Badan Lahir Rendah) dan Pemberian ASI Eksklusif Terhadap Perubahan Status Stunting Pada Balita di Kota dan Kabupaten Tangerang Provinsi Banten. Prosiding Seminar Nasional "Peran Kesehatan Masyarakat dalam Pencapaian MDG's di Indonesia"; 12 April 2011.

7. Zottarelli LK, Sunil TS, Rajaram S. Influence of Parental and Socioeconomics Factors on Stunting in Children Under 5 Years in Egypt. Eastern Mediterranean Health Journal [internet]. 2007 [cited 2013 May 5]. Tersedia di: http://www.emro.who.int/emhj/1306

8. Nasikhah R. Faktor Risiko Kejadian Stunting Pada Balita Usia 24-36 Bulan di Kecamatan Semarang Timur. Program Studi Ilmu Gizi Fakultas Kedokteran Universitas Diponegoro. Semarang; 2012.

9. Candra A, Puruhita N, Susanto JC. Risk Factors of Stunting among 1-2 Years Old Children in Semarang City. Media Medika Indonesia 2011; 45: 206-212.

10. Fernald LC, Neufeld LM. Overweight With Concurrent Stunting In Very Young Children From Rural Mexico: Prevalence And Associated Factors. European Journal of Clinical Nutrition 2007; 61: 623-632. [accessed February 29, 2013]. Available from:

URL: http://www.nature.com/ejcn/journal/v61/n5/pdf/16 02558a.pdf/

11. Chaudhury RH. Determinants of dietary intake and dietary adequacy for pre-school children in Bangladesh. Bangladesh Institute of Development Studies. [accessed March 29, 2013]. Available from:

URL: http://archive.unu.edu/unupress/food/8F064e/8F06 4E04.htm 
12. United Nations Children's Fund. World Health Organization. The World Bank. UNICEF-WHOWorld Bank Joint Child Malnutrition Estimates. UNICEF, New York; WHO, Geneva; The World Bank, Washington, DC. 2012.

13. Diasmarani N. Karakteristik dan Perkembangan Bahasa Anak Balita Stunted di Desa Sukawening, Kabupaten Bogor. Departemen Gizi Masyarakat Fakultas Ekologi Manusia Institut Pertanian Bogor. Bogor; 2011.

14. Dinas Kesehatan Provinsi Jawa Tengah. Profil Kesehatan Provinsi Jawa Tengah. Semarang; 2011.

15. Checkley W, Epstein LD, Gilman RH, Cabrera L, and Black RE. Effects of Acute Diarrhea on Linear Growth in Peruvian Children. America Journal Epidemiology [internet]. 2003 [cited 2013 August 2]. Tersedia di : http://aje.oxfordjournals.org

16. Badan Pusat Statistik Provinsi Jawa Tengah. Data Garis Kemiskinan Kota Semarang [internet]. 2010 (update tanggal 1 Mei 2013; diunduh tanggal 6 Mei 2013). Tersedia di : http://jateng.bps.go.id

17. Kusharisupeni. Peran status kelahiran terhadap stunting pada bayi: sebuah studi prospektif. Jurnal Kedokteran Trisakti. 2002; 23: 73-80.

18. Kiely JL, Yu S, Rowley DL. Low Birth weight and intrauterine growth retardation. CDC public health surveillance for women, infants and children. [serial online] [cited 2013 March 12th] Available from: URL: http://www.cdc.gov/

19. Rahayu L.S, Julia M, Gunawan I.M.A. Associated of height of parents with change of stunting status from 6-12 month to 3-4 years. thesis. Program Pascasarjana Fakultas Kedokteran Universitas Gadjah Mada, Yogyakarta. 2011

20. Jesmin A, Yamamoto SS, Malik AA, Aminul Haque,MD. Prevalence and Determinants of Chronic Malnutrition among Preschool Children: A Cross-sectional Study in Dhakka City, Bangladesh. J health Pop Nutr. 2011 Oct;29(5):494-499

21. Supariasa IDN, Bachyar B, Ibnu F. Penilaian Status Gizi. Jakarta: EGC; 2002. hlm 18-20, 28, 71, 34-35, 94-96, 114, 177, 181, 187-188

22. Amigo $\mathrm{H}$, Buston $\mathrm{P}$, Radrigan ME. Is there a relationship between parent's short height and their children's? Social interclass epidemiologic study. Rev Med Chil 1997; Aug;125(8)

23. Astari LD, Nasoetion A, Dwiriani CM. Hubungan Karakteristik Keluarga, Pola Pengasuhan dan Kejadian Stunting Anak Usia 6-12 Bulan. Media Gizi dan Keluarga 2005; 29 (2): 40-46.

24. El Taguri A, Betilmal I, Mahmud SM, Ahmed AM, Goulet O, Galan P, Hercberg S. Risk factor for stunting among under-fives in Libya. Public Health Nutrition 2008; 12(8), 1141-1149. doi: $10.1017 /$ S1368980008003716.

25. Musthaq MU, Gull S, Khursid U, Shahid U, Shad MA, Siddiqui AM. Prevalence socio-demoghrapic correlates of stunting and thinnes among Pakistani primary school children. BMC Public Health 2011; 11:790. [diakses 10 Mei 2013]. Available from: http://www.biomedcentral.com/1471-2458/11/790

26. Vitolo MR, Gama CM, Bortolini GA, Campagnolo PDB, Drachler MDL. Some risk factors associated with overweight, stunting and wasting among children under 5 years old. Jornal de Pediatria 2008; 84:251-257. [accessed December 27, 2013]. Available from: http://www.scielo.br/pdf/jped/v84n3/en_v84n3a11. pdf

27. Chaudhury RH. Determinants of dietary intake and dietary adequacy for pre-school children in Bangladesh. Bangladesh Institute of Development Studies. [accessed March 29, 2013]. Available from:

URL: http://archive.unu.edu/unupress/food/8F064e/8F06 4E04.htm 